\title{
Transformations of the Evil Forest in the Swedish Television Series Jordskott
} An ecocritical reading

\author{
Irina Souch
}

Department of Modern Foreign Languages and Cultures, University of Amsterdam, The Netherlands

\begin{abstract}
This article is an ecocritical reading of the Swedish television series Jordskott. I discuss the effects in the series produced by the combination of the Nordic Noir's style and narrative techniques with elements of other genres, especially Gothic horror. I argue that through the contemporary reworking of the centuries-old Nordic mythology, Jordskott demonstrates how the aggressive powers of nature in Gothic narratives can no more be conventionally explained by referring to the pagan, pre-Christian beliefs, but need to be reconceived in light of the relentless environmental devastation brought about by humankind. The link unveiled between natural ecology and cultural mythology allows the series to surpass the limitations of the regionally informed folkloric story and to evolve into an ecological cautionary tale of global significance.
\end{abstract}

Keywords: environmental criticism, ecoGothic, serial television, fantasy, Jordskott

\section{Introduction}

Nature wants to tell us something!

Olof Gran (Jordskott, 2015, episode 5)

A crucial scene in the Swedish television series Jordskott features the retired inspector Olof Gran attempting to intervene in a press conference at the police quarters of a small provincial town, Silverhöjd. Questioned by journalists, the police struggle to explain the succession of crimes plaguing the place, ranging from the heavy contamination of the river to mysterious disappearances of young children and brutal murders of senior citizens. While the media speculate about terrorist attacks and the possible invasion of vicious monsters who persecute the people, Gran's emphatic assertion that the town's predicament is caused by the prolonged human infringement on the surrounding nature remains conspicuously unheard. From this scene on, Jordskott's narrative maintains a critical focus on humankind's relation to nature, to challenge the dominant mindsets and

Souch, I. (2020). Transformations of the evil forest in the Swedish television series Jordskott: An ecocritical reading. Nordicom Review, 41(Special Issue 1), 107-122. https://doi.org/10.2478/ nor-2020-0011 
to invite a reimagining of the entanglement of human enterprise and wellbeing with the suffering and pain of the environment.

The Nordic countries conceive of themselves as highly ecologically conscious. The consistent pursuit of an ecologically sustainable societal model is clearly illustrated by the 2017 Nordic Council of Ministers' campaign, Nordic Solutions to Global Challenges, which ascribes a great significance to the long-term environmental cooperation between the partners (Nordic Council of Ministers, 2017). Internationally, Norden's reputation as environmental forerunner is supported by the fact that already in 1972, Sweden took the initiative to host the first United Nations conference on environmental issues in Stockholm. The above discourse, however, stands in tension with the extensive exploitation of natural resources the Nordic countries carry out to support their highly developed welfare systems. It is telling, for instance, that Sweden is ranked, by the World Wide Fund for Nature, at number ten in the list of the most resource demanding and polluting countries in the world (WWF, 2014). The centuries-long reliance of Norwegian economy on the fossil fuel trade, in turn, feeds into the public feelings of what Ellen Rees (2016: 45) calls "petro-guilt that is a by-product of the collision between a social democratic ideology predicated on solidarity, equality and democracy, and the enormous wealth generated by the offshore oil and gas industry". However, as Rees further argues, as the sense of moral superiority continues to dominate political and cultural discourses, "the complexities of guilt and privilege that underlie the Norwegian "oil fairy tale"" are often disregarded or even effaced (2016: 47).

The paradoxical coexistence in the Scandinavian collective consciousness of the environmentalist self-perception and the disturbing awareness of the detrimental effects human industrial activity has on the "nationalized nature" (Kääpä, 2014: 12) has lent itself to a large array of literary and cinematic interpretations, the importance of which cannot be overestimated. In their recent edited volume, Nordic Narratives of Nature and Environment, Reinhard Henning, Anna-Karin Jonasson, and Peter Degerman (2018: 5) contend that "various forms of cultural production can contribute to a better understanding of historical developments that contributed to the construction of the Nordic countries' contemporary green image" and thus open the way for the critical reappraisal of their "environmental exceptionalism". In the same vein, film scholar Pietari Kääpä (2014: 25-26) asserts:

Critical interdisciplinary exploration of the diversity of Nordic ecocinema can not only make a significant contribution to the study of Nordic cultures, but also to bring back political participation to a field which has lost some of its explicit engagement with political issues.

Remarkably, eco-critical fiction has been rather late to come to television and has only recently been taken up as a worthy subject for the internationally acclaimed Nordic Noir quality serial drama. The most illuminating examples of this newly kindled interest in environmental problematics are the Norwegian series Occupied (2015-) and the Swedish ITV Encore series Jordskott (2015-). ${ }^{1}$ Whereas Occupied has received considerable scholarly attention (cf. Leyda, 2018; Mrozewicz, 2018; Saunders, Mrozewicz, and Dodds \& Hochscherf, in this issue), Jordskott's environmentalist streak has, up until now, remained underexposed except for Jørgen Bruhn's brief discussion of the ecocritical imagery of its opening sequence (Bruhn, 2018). In this article, I analyse the show's 
first season with an aim to flesh out its capacity to contribute to raising environmental consciousness.

The fast-growing field of ecocinema scholarship has demonstrated that "it is important, in an era of expanding media universes, that critics look at mainstream as well as alternative uses of visual media" (Ivakhiv, 2008: 24) in order to "actively disrupt the distinctions and assumptions generated by traditional genre focus" (Rust \& Monani, 2013: 4 ), and to broaden our understanding of all cinema as "ecologically embedded" (Rust \& Monani 2013: 4). Expanding generic boundaries further, Julia Leyda (2016: 16-17) asserts that popular "quality" television series often bear textual and visual traces of what she calls the "climate unconscious", fostering baseline awareness of the anthropogenic footprint even when their narratives do not explicitly revolve around environmental issues. Although, as David Ingram (2013) notes, (eco)critical cultural meanings may not be always acknowledged by viewers depending on their prior predispositions and training, various modes of these texts' circulation together with the heterogeneity of their audiences always encourage multiple interpretations, and it is within this dynamic cultural field that dominant ideologies can be both reasserted and contested (cf. Hall, 1980). Leyda rightly contends that "engrossing audiences in [...] fictional narrative means allowing them to process emotionally the implications of what they may well already know via facts and figures" (Leyda, 2016: 14). In line with this special issue's take on television as a part of the "discursive battlefield of global politics" (Saunders, 2017: 983), I would also like to point out that the growing global appreciation of dramatic serials makes them particularly well suited for influencing multiple audiences' understanding of how the world works and what it will become. The long-term engagement with the televisual form of storytelling, moreover, increases viewers' cognitive and affective investment in the narrative conflicts, thus endowing television with an even more powerful pedagogical potential compared to cinema. Representing this new generation of transnationally distributed and consumed popular narratives, Jordskott, I argue, effectively challenges viewers to retrain their perception of ecological awareness.

\section{Genre hybridity and environmental connotations}

Already in the early stages of the narrative, viewers are given an inkling of Jordskott's central thematic concern when Olof Gran (Hans Mosesson) warns the protagonist, criminal inspector Eva Thörnblad (Moa Gammel) of the perils she is about to experience:

Why do you think Silverhöjd forest remained untouched for such a long time? It stayed that way until your father took it over. And now yet another child is missing. There are forces in nature that can become dangerous if you harm them. Believe me or not, but you are in danger as long as you stay here. (Jordskott, 2015, episode 2)

Several years previously, Gran had been in charge of the failed investigation into the disappearance of Eva's six-year-old daughter Josefine during a picnic at the Silverhöjd lake. Today, Eva returns to her hometown to arrange her father's funeral but decides to stay when she learns that a young boy has gone missing in the Silverhöjd forest in a similar way to Josefine. It transpires that long before his death, Eva's father, who owned the Thörnblad cellulose and mining company, violently cleared vast expanses of the forest, destroying all living organisms and thus transgressing the mythical laws 
of nature according to which "the people of the woods" lived in harmony with humans since the ebbing of the last Ice Age, when Scandinavia was first settled. Eva is thus led to believe that her daughter was abducted by the old forest inhabitants as a gesture of retaliation for the historical ecocide. The more recent abduction also seems to have a causal connection with the current company board's plans for invasive mining activities which present a major threat to the precarious environmental balance.

Jordskott was first broadcast in June 2015, running for two seasons on the Swedish public broadcaster SVT. The first season drew an average of 1.5 million viewers in Sweden, and was sold to 55 countries (Nordic Fantasy, 2017). The series enjoyed immediate popularity among domestic and foreign audiences who praised it for introducing to the small screen "something completely different - a Scandinavian crime drama with serious supernatural/horror overtones that is unlike anything that's come out of the region for a long time" (Hirons, 2015a: para.1). Intrigued by the enigmatic, untranslatable title referring to a fictional natural parasite with healing and performance-enhancing powers - a fact revealed only midway through the story - enthusiastic viewers identified ancient Swedish myths about elves and trolls as the sources of inspiration for the series while also spotting textual references to David Lynch's 1990s classic Twin Peaks (Donaghy, 2015a). To highlight the innovation of the series, its creator Henrik Björn was quoted in an interview, claiming that "it starts as a normal crime story, but it soon takes a detour... It will end up in a very different place compared to where it started. It is a genre mashup" (Donaghy, 2015a: para. 2). Accordingly, the online magazine Killing Times commented on Jordskott's appeal to widely divergent audiences as "a police procedural, a supernatural drama, a family drama and an environmental drama all rolled into one" (Hirons, 2015b: para. 14), whereas The Guardian's critic James Donaghy expressed his appreciation of the show's artful engagement with the local Swedish folklore in combination with the globally circulating horror imagery by calling it "the fairytale-noir monster mash-up" and "an eco-friendly journey into a heart of darkness" (Donaghy, 2015b: para. 1).

What stands out in the above quotes is the notion of different genres brought together in a particular constellation. Genre hybridity, a phenomenon frequently practiced in cinema to achieve broad resonance across genre boundaries and audience groups (cf. Altman, 1999; see also Wright, 2010, for a Scandinavian example) has by now also become a well-established trend in transnational television drama because "producer risk is perceived to be reduced if elements of previously successful TV vehicles might be woven together in a new, and hopefully even more colourful, braid" (Nelson, 2015: 10). By transcending genre-specific expectations, each unique melange of innovative and familiar generic features possesses a capacity not only to ensure richer viewer demographics but, more importantly, also to open up uncountable productive spaces for multilayered and complex narrative structures and engage audiences on intellectual and affective levels. And it is exactly this layering, in Jordskott, of two particular generic strands - namely Nordic Noir and the so-called telefantasy - that challenges contemporary viewers to retrain their perception of ecological awareness while moving across the boundaries of individual, local, and global anxieties and preoccupations. The unconventional combination of Nordic Noir as the proven catalyst of Scandinavian drama's transnational success with telefantasy can be certainly seen as an innovative endeavour. In television studies, telefantasy serves as an umbrella term for a broad variety of genres "united by their 
representation of the otherworldly and unreal" (Johnson, 2015: 57). Many contemporary television scholars see telefantasy as a potentially subversive genre (Jackson, 1981; Neale, 2000; Spigel, 2001). Steve Neale, for one, explores such subversive potential by introducing the notion of cinematic verisimilitude. He argues that in a film (or television programmes) verisimilitude always works at two levels: sociocultural, marking out what is believed to align with the lived reality, and generic, defining what is plausible according to the conventions of a particular genre. Both types structure viewers' systems of expectations and organise their interpretation and understanding of cultural texts (Neale, 2000). Through its portrayal of other realities which operate according to special sets of rules and conventions, telefantasy challenges sociocultural verisimilitude. However, viewers still invest in these representations not only because of their ability to engender the pleasure of the unexpected, but also because of their conformity to the principle of generic verisimilitude. The creation of "a story-world that is different from the realities of our everyday world but still convincing and plausible" (Johnson, 2015: 57) makes telefantasy exceptionally suitable for bringing forward the issues of cultural critique and proposing alternative paths of imagining things.

As Amitav Ghosh contends in his seminal book, The Great Derangement, environmental criticism is especially difficult to convey by using conventional realistic forms of representations, which fall short of giving shape to something as unprecedented and unimaginable as the large-scale overexploitation of natural resources and climatic change (Ghosh, 2016). The gradual realisation of human culpability for the warming planet and their own demise has given rise to a large spectrum of approaches and unconventional genre destinations attesting to "a demand for new categories in what we must admit is a new era" (Leyda, 2016: 14). To emphasise the didactic capacity of fantastic genres, writer Sheree Renée Thomas (2014: para. 3-4) argues:

There is power in fantasy, especially in stories that urge us to face the impossible or find ways to survive [...]. The best stories take us inside of storytelling so seamlessly, that when we emerge, the impossible is easier to imagine. This fiction creates a space in our minds to consider other perspectives and adopt new solutions.

The close reading of certain thematic and visual tropes in Jordskott therefore allows us to consider how a mixture of realist and fantastic genres can be productively employed to point out the unsustainability of industrially over-developed Western lifestyles, and to teach viewers lessons in ecological thinking.

Jordskott opens with a succession of shots depicting the yellowed pages of old maps, faded photographs of people and landscapes, ominous-looking drawings of tree roots replicated in overexposed X-ray images, newspaper clippings about Thörnblad lumber company's cutting down a thousand-year-old forest shown next to the poster announcement of a missing child, and finally, the animated fragment of a flock of black crows in a bare field, flying off a tree towards the viewer. The juxtaposition of separate shots implies that the ills Silverhöjd is presently enduring, including the disappearance of children and the spreading of unexplainable deathly diseases, are directly related to the past when, fuelled by corporate greed, industrial interventions irrevocably destroyed the ancient precarious balance between the town and nature. Before changing, each frame becomes inundated with the slowly spreading red-brownish matter, which, as Bruhn (2018: 70) suggests, indicates the "biological, but destructively unhinged, growth". 
Although it soon transpires in the series that the viscous liquid symbolises the proliferation of a parasitic tissue in the human body, the image also provokes an association with blood, and through this, another cultural text that deserves mentioning as one of Jordskott's notable predecessors.

In 1994, Lars von Trier directed a four-part television mini-series Riget [The Kingdom], which became one of the most popular serial productions in the history of Danish broadcasting (Tangherlini, 2001). The series depicts a large hospital as the setting for a contemporary ghost story. Von Trier's primary innovation lay in the ironic mixing of a variety of popular genres - such as the hospital drama, detective, horror, comedy, and soap opera - to offer a multilayered critique on positivist hospital discourse, government-sponsored medical science, and the contemporary Danish welfare state in general. Jordskott's credits design echoes the muted sepia colour scheme of Riget's opening sequence, and the spreading pool of reddish liquid disturbingly resembles the ruby-red blood spilling profusely from the word "Riget" carved on a cracked wooden surface, introducing the title. Obfuscated by sluggish human shapes trudging through water, the subsequent sequence shows what seems to be weeds, moss, and dead wood. The grave voice of the narrator explains that "the Kingdom hospital rests on the ancient marshland where the bleaching ponds once lay". It has been observed that von Trier here clearly refers to the Danish legend tradition, in which swamps and bleaching fields usually feature as sites of infanticide, to set his own ghost story in motion (Tangherlini, 2001). When the voiceover concludes the introduction with an ominous announcement that "the gateway to the kingdom is opening once again", viewers are invited to interpret the notion of kingdom "narrowly as the hospital, more broadly as the Danish kingdom, and even more broadly (and metaphysically) as the world beyond" (Tangherlini, 2001: 10). The narrator's warning uncannily reminds us of Olof Gran's attempts to make the public aware of the damage done to the environment and of nature's subsequent revenge on humanity. Although not explicitly ecological, Riget's narrative similarly aims to draw attention to the idea of retribution, when a repressed natural landscape emerges from beneath the modern structures built atop and starts undermining them in unpredictable and frightening ways. Apart from the visual plane, Jordskott's connection to Riget can thus be spotted in the figure of the narrator who, many years before Gran, sought to point out the dire consequences of modern development displacing the old natural order.

The comparison to Riget is productive in an additional sense. By focusing on "the state of Denmark as a country in the fragmentary times of the global age" (Peacock, 2009: 27) and by highlighting various critical aspects of national life, von Trier's series was primarily targeting a domestic audience. As Glen Creeber (2004: 57) remarked at the time, "the Rigshospital [...] offers the viewer a contemporary television drama that actively goes against the apparent tide of global television practice, presenting a less than conventional television narrative centred around issues of a uniquely local nature". Twenty years on, we witness how Scandinavian television productions have gained recognition in several parts of the world, not in the least because of their creative blending of art-house and mainstream genres, aesthetics and forms of narration, but also because of their conscious attention to globally familiar concerns and preoccupations. While inheriting from the ground-breaking genre experiments in Riget, Jordskott also aligns with the more contemporary trends in globally celebrated Scandinavian drama. And it 
is exactly the intertwining of the Nordic Noir detective storyline with the strands of telefantasy that makes the environmental theme strikingly resonant with transnational viewership.

On the one hand, the realistic depiction of the economically motivated crime drives the ecological message home with acute precision. From the start, we are made cognisant of the approaching catastrophe as a direct repercussion of the Thörnblad company board's decision to ignore the outcomes of the geophysical survey, according to which the continuation of mining operations in the Silverhöjd's area would drastically augment the risks of land dislocation and earthquakes. In spite of this knowledge, the company's present CEO, Gustav Borén, is shown intimidating and bribing the environmental inspector in order to push his industrial plan through. On the other hand, as the opening sequence foreshadows, multiple leads in the crime investigation are inexplicably lost in the Silverhöjd forest, prompting the police to acknowledge that they need to "think bigger". When, in episode 2, Eva hears Gran's emphatic assertion that her father's ruthless violation of the centuries-old treaty between humans and nature triggered the wrath of the forest, resulting in harm to the local community, we have little doubt as to the true reason of the present predicament. Instead of reproducing the conventional movement through which "actual landscapes become symbolic landscapes" (Meinig, 1979: 174), the forest in Jordskott capitalises on its symbolic function to claim its material status to direct viewers' attention towards economic and political issues of development and exploitation of natural resources. To move towards the understanding of how this is done, the next section considers the position forests occupy in European cultural imagery, and in particular, in folkloric narratives.

\section{Forest as a natural landscape and a folk tale space}

As one of the most classic folktale landscapes, the forest is strongly associated in the popular imagination with unconscious, forbidden desires, adventure, secret forces, inexplicable phenomena, and rites of initiation. As "a passage-way of particular importance" (Messerli, 2005: 274), the forest is a space where protagonists of many folkloric stories must journey in order to discover their destiny and place in the world. It is often there that they gain a sense of what is to be done. In his book, The Uses of Enchantment: The Meaning and Importance of Fairy Tales, child psychologist and writer Bruno Bettelheim (2010: 93), for instance, contends that the fantasy forest "symbolizes the place in which inner darkness is confronted and worked through; where uncertainty is resolved about who one is; and where one begins to understand who one wants to be". The capacity of forests to act as places of ultimate trial and transformation is underscored by the renowned folklorist Jack Zipes (2002: 65), who writes:

The forest is always large, immense, great, and mysterious. No one ever gains power over the forest, but the forest possesses the power to change lives and alter destinies. In many ways it is a supreme authority on earth and often the great provider.

This rich imagery owes its potency to the fact that, since primeval times, forests have constituted a distinct characteristic of northern Europe's geographical and cultural space. According to cultural historian and literary scholar Robert Pogue Harrison (1992: ix): 
Western civilization literally cleared its space in the midst of forests. A sylvan fringe of darkness defined the limits of its cultivation, the margins of its cities, the boundaries of its institutional domain; but also the extravagance of its imagination.

In the same vein, fantasy writer Sara Maitland contends that forest imagery has been particularly productive for northern European folklore's themes and ethics exactly because of a forest's easy availability as a suitable location for fantastic events: "The forest is the place of trial in fairy stories, both dangerous and exciting. Coming to terms with the forest, surviving its terrors, utilizing its gifts, and gaining its help is the way to 'happy ever after'” (Maitland, 2012: 8).

The aforementioned views imply that in fairytales and myths, landscapes possess an equal and sometimes even greater power than people, and magic events usually occur through "contacts with the inhuman - trees and creatures, unseen forces" (Byatt, 2003: para. 6). In spite of presenting simplified versions of nature,

for audiences seeking entertainment but also a fairy tale format through which they can make sense of, and critique, today's social order, landscapes reflective of not only our cultural past but also current social realities and spatial relationships are used. (Kennedy et al., 2010: 284)

The emphasis put in critical literature on "the reciprocal relationship between place and imagination" (Brace \& Johns-Putra, 2010: 20) as being always realised within a specific frame of sociocultural conditions also suggests that conventional popular tropes are prone to historical change and can be reconfigured into a new natural iconography to reflect today's cultural anxieties, one of which is environmental crisis. Seen through this contemporary lens, locally produced and circulated ancient legends about nature can become intelligible for a much larger diversity of audiences and even acquire transnational currency.

Using the immense dark forest as the main location of a Swedish television series is not surprising. Jordskott's leading actress, Moa Gammel, commented extensively on this choice long before the series was aired. Gammel said the following in an interview:

I think Sweden is $80 \%$ forest or something like that - it's crazy! So the forest, of course, is part of our national identity and we have these beautiful forests to submerge ourselves into. I think the audiences are going to be seduced by that setting as well. (Smyth, 2015: para. 39)

Indeed, as journalist and writer Maciej Zaremba reminds us, for Swedish people, forests constitute a natural arena for the multitude of daily practices and routines. Accordingly, the most preferred living location in Sweden is a luxuriant green area at the verge of a wood and a sizable distance from other dwellings to ensure privacy, and the most popular pastime is a contemplative healthy walk in a tree-rich environment (Zaremba, 2013). Zaremba also notes that forests are perceived to be the stronghold of Sweden's cultural origins and the so-called national spirit. One of the markers of this deeply-rooted collective identification is the fact that many Swedish surnames contain references to various tree species and types of wood. ${ }^{2}$ In addition to Zaremba's observations, Yvonne Leffler points out the highly ambivalent status of forests in Swedish cultural imagery, because they simultaneously represent "the sanctuary from the stress of city life" and the alienating and threatening place that contains "the remains of a mythical, pagan and agonizing past" (Leffler, 2013: 151). 
Indeed, the Silverhöjd forest in Jordskott features as both a physical location and an eerie space of a fairytale. On the one hand, it constitutes the rustic habitat zone of the principal characters and the site of economic activity of the Thörnblad company. Under its leafy canopy, the local youths congregate and make mischief. It is in the forest's impenetrable darkness that Eva both loses and finds her daughter Josefine, and where the other missing children are believed to be held. On the other hand, the dense green thickets conceal ancient secrets, provide a stage for strange phenomena, inform collective memories, and host individual spiritual experiences. Moreover, the forest's untamed wilderness is populated with mysterious beings stemming directly from the Scandinavian folkloric tradition. Jordskott's narrative accommodates a subplot of an orphaned young girl, Esmeralda, who is a huldra - a beautiful female creature endowed with superpowers who acts as a keeper of caves and mines, and is related to other forest dwellers living in chthonic spaces. There is also a family of three brothers who hide their identities as trolls to assimilate in the town's community and who eventually fall victim to one of the human character's vengeful actions against "evil monsters". Finally, the chain of puzzling events in the series starts with the discovery of a dead näcken - a shape-shifting water spirit traditionally believed to lure humans into drowning (Trimble, 2019). Whereas Scandinavian viewers may recognise the reference to folkloric leitmotivs and attribute significance to them accordingly, Jordskott's orientation towards transnational audiences suggests that the inclusion of other-than-human personages might serve a larger goal than the pure exaltation of the national spirit or, even, the genre-related augmentation of suspense.

Although the ultimate truth about the historic ecocide that made the ancient forest tribes perish would be revealed only towards the end of season two, and as such reaches beyond the scope of this article, it deserves noting that the narrative of the series consistently subverts traditional presentations of supernatural characters as dangerous monsters. Instead, it emphasises time after time the ability of humankind to relentlessly infringe on, cause harm to, and even eradicate other Earth species, be they mythical or real. The story of the näcken is particularly illuminating in this sense. The spirit emerges in the shape of a gigantic greenish-white male figure, with fins instead of hands. In the first episode, it is shot at with a rifle by the local youths playing in the woods and is shortly after killed by the water turbine on the premises of the Thörnblad company. The näcken's tragic fate foreshadows the town's subsequent ordeals, which include the contamination of the water in the sylvan stream and in the Silverhöjd lake. Another detail worth mentioning is that when the creature's dead body is laid out at the pathologist's table, it literally loses its form and dissolves into a slimy yellow matter. In an uncanny way, the scene is evocative of Timothy Morton's remark that in order to learn how to deal with contemporary ecological problematics, environmental imagery should not be limited to the contemplation of "pretty or sublime pictures of nature", but needs to concentrate on the formless, the miasmic, and the polluted, that is, "to hold the slimy in view" (Morton, 2015: 250). In other words, in order to learn how to think ecologically, we should not content ourselves with the aesthetical consumption of beautiful natural scenery from the comfortably distant spectatorial position, but need to fully comprehend our intrinsic entanglement with other (non-human) ecologies and species, including "things that glisten, schlup, and decay" (Morton, 2015: 250). Morton's views have immediate implications for the next section, which will further unpack the role of the Silverhöjd 
forest not only as the story's evocative setting, but as its central character and the active proponent of ecological thought.

\section{Silverhöjd forest as a Gothic character}

Despite many critical dimensions a real (or imaginary) forest displays in European and in particular Swedish - culture, the previous descriptions still conceive of it as a natural backdrop for human activity. Yet, a thorough analysis of Jordskott helps to challenge these conceptualisations by arguing that the Silverhöjd forest supersedes its auxiliary function to assume a crucial role in the mediation of specific living experiences that may accrue towards ecological thinking. This happens through the interplay of both genre-conformant and innovative strategies the series pursues. Owing to its generic hybridity, Jordskott employs a large variety of aesthetic and narrative techniques to insert the natural environment into the story. Thus, following Nordic Noir conventions, it offers extensive panoramic shots of the boundless woodlands, the majestic meandering river, and the mist-covered, silvery-blue rocks, complimented with numerous aerial views of the dense emerald foliage. The long panning shots of the scenery undeniably possess aesthetic autonomy of the landscape in Martin Lefebvre's sense, enabling viewers to shift their attention from the diegetic action toward the "background" and thus engage in the spectacular, contemplative mode (Lefebvre, 2007: 29). The ability to solicit viewers' contemplation constitutes the hallmark of the Nordic Noir genre, known for its consistent figuration of atmospheric or, as Kim Toft Hansen and Anne Marit Waade (2017) call them, "evocative" landscapes associated with a particular sense of displacement, nostalgia, and melancholic ambiguity (see also Waade, 2017). ${ }^{3}$ To that extent, Creeber (2015) also claims that by exuding an unsettling "mood of eerie melancholy" (22), Nordic Noir's desolate landscapes not only define psychological dynamics of the narrative, symbolising bleak, lonely, and isolated lives of the characters but, most importantly, hint that complex hidden connections at play in society "may sometimes work on a level beyond all human rationality" (29). The latter notion already hints at Nordic Noir's affinity with fantastic genres, and in particular, with horror, which in Norden is often informed by the regional folkloric tradition and "revolves around a certain type of landscape or Gothic topography, the Nordic wilderness, weaving the landscape into the story rather than using it as backdrop for the action on stage" (Leffler, 2013: 141).

In a smooth oscillation between the generic conventions of Nordic Noir and horror, the Lefebvrian mode of detached contemplation (to which Morton is so insistently opposed in his ecological writing $)^{4}$ in Jordskott evolves in a rather different form of spectatorial engagement. While in the beginning we tend to dispassionately appreciate the impressive panoramas, perceiving them as an artistic portrayal of diegetic reality, soon the monumental images start to affect us on a visceral level, to unsettle our senses and to suggest the existence of the unknown forces that transcend the imaginative realm and cannot be represented. Eschewing aesthetic meditation of the landscape's externality, the narrative instead gradually reorients our focus towards the internal events which now include the forest as a dramatic character in its own right. Becoming a true suspect, it moves from the peripheral position of the story's setting into the very centre of the diegetic action or, to use Les Roberts's (2016: 379) apt formulation, “in the frame; not 
in the pictorial or formal sense, but with reference to questions of motive and causation [emphasis original]".

We discover that many glamorous images of nature, which initially seemed to be included to facilitate transitions between scenes and to serve as intermezzos - or temps morts as Lefebvre (2007) calls them - belong to the diegesis proper and therefore are not arbitrary or free of narrative motivation. With every recurrent shot, the appearance of familiar locations changes, unveiling the facets of the story previously unnoticed or unacknowledged. The expanded rolling takes of the dense dark foliage at the beginning of each episode enhance our awareness of the forest's vastness and impenetrability. Time after time, the human protagonists lose their sense of orientation when they need to navigate between the claustrophobically tight rows of tall straight pines, bushes, and ferns, treading carefully on the unstable surface of the exuberant spongy mosses. Numerous frames offer a view on the characters' movements in and around their houses through the filter of interlacing leaves, which augments the uncanny atmosphere implying that the people are being watched by the trees. As the narrative unrolls, it transpires that the greenish rock in the gloomy, overgrown section of the forest to which Eva feels inexplicably drawn conceals an entrance to a cave with an intricate network of underground passages, where the abducted children would eventually be found.

Especially indicative are the successions of takes allowing the panoramic views to be followed by the medium and close-up shots of the thick formations of bushes and trees and, shortly after, by the images of cut tree trunks and barren sandy spots covered with dead, mouldy branches. In a number of such sequences, the final frame shows the crumpled leaflet, with a photograph of the missing boy Anton Leander, stuck in the broken twigs and dry leaves scattered on the ground. While Eva and the police persist in their pursuit of a human perpetrator, we are led to understand that the string of unexplained murders, deaths, and abductions is provoked by the years of Thörnblad factory's relentless encroachment on the forest's vulnerable ecology. Popular ecodrama usually shows the moment of the human protagonist's coming across the theatre of environmental destruction as a starting point of their journey to ecological awareness. In Jordskott, however, the actual ecocide and its long-lasting detrimental effects are explained only towards the end of season one. This produces a rather different narrative dynamic. Before the criminal deeds of the cellulose company are finally brought to light, the ecological message is driven home in an oblique manner through the innovative invocation of Gothic tropes. Apart from generating suspense, the move towards the increasingly unfamiliar space of a complex and bewildering world of alien lifeforms effectively prompts spectators to question the conventional species-related issues in an ecological context. Through this shift of focus, the series aligns with the relatively new area within Gothic fiction - the so-called eco-Gothic.

Recent works of Andrew Smith, William Hughes, and David del Principe illuminate "how current ideas about Ecocriticism can be applied to Gothic narratives in order to help draw on their often dystopian ecological visions" (Smith \& Hughes, 2013: 4). By complementing ecocriticism with ideas from posthumanism, ecofeminism, and animal studies, eco-Gothic ultimately seeks to challenge the anthropocentric gaze on nature and to (re)consider and (re)formulate theories about environmental and species' identities (Del Principe, 2014). This line of enquiry is much indebted to Morton's ecological insights, and in particular to his assertion that the scope and complexity of the environ- 
mental crisis cannot be apprehended in a single glance (Morton, 2013, 2016). ${ }^{5}$ The reason for this lies not only in the "split between the (real) knowledge and (symbolic) belief" resulting in the situation when "we are already on the brink of catastrophe [...] but nevertheless we do not believe it”, as Slavoj Žižek (1992: 27-28) once famously asserted, but also in the very limitation of human sight, which can only vaguely perceive snapshots of the whole picture at once. As a consequence, the effects of the anthropocentric mastery over the environment often appear as instants of uncanny encounters with strangeness, as a moment of Gothic intimacy, and as a sudden inkling or intrusion that can never fully be made visible. For Morton (2010: 9), true ecological thinking demands "reframing our world, our problems and ourselves"; it solicits the radical reorientation of our senses which is only possible through the acceptance of our intrinsic interconnectedness and intertwinement with the full variety of human and nonhuman lifeforms. In other words, environmental awareness is a laborious endeavour imbued with an uncanny feeling, "as if we were seeing something we shouldn't be seeing, as if we realized we were caught in something" (Morton, 2010: 58). In light of Morton's theory, eco-Gothic emerges as a green genre par excellence, since it unveils how the feelings of terror that overcome Gothic subjects upon their confrontation with nature's untamed wilderness can potentially render interactions with the environment fraught with violence and destruction. At the same time, eco-Gothic narratives go beyond the conventional Gothic conception of nature as always terrifying, to depict it as an agent with its own logic, "as a living, acting, alien other" (Tyburski, 2015: 133) that is not necessarily an adversary to humans and therefore does not need to be incessantly mastered and controlled.

In Jordskott, the forest's transformation into a living and evolving organism, endowed with personal history, psychological complexity, and agency, does not proceed along a linear trajectory but is brought in synchronicity with the slowly unravelling economic plot knot.

This is exactly when the Gothic intrigue gains momentum. And although contemporary Scandinavian horror is known to always be substantially place-oriented (cf. Leffler, 2013), the series surpasses the usual tendency to relate the landscape's terrifying interventions with the human endeavour to the forgotten knowledge of the pre-Christian pagan and mythical past. The agonising past it invokes is by no means far removed from the people's memory. What is more, regardless of the growing protests of the town's inhabitants, similar catastrophic events threaten to be repeated in the present. And yet, the Silverhöjd forest succeeds in defying its oppressive status of an industrial object, or a piece of domesticated nature, analogous to the landscape paintings adorning the police station's walls. Instead, it positions itself as a vengeful agent taking hostages and disrupting the allegedly harmonious existence of the community. While the human protagonists struggle to perceive the totality of the pending environmental disaster, the forest sets out to direct their decisions and behaviour.

The absence of a human offender to account for the children's abductions enables Jordskott not only to destabilise the Nordic Noir detective conventions, but also to radically reconfigure some of the classic Gothic tropes. Viewers never come to see the mysterious (anthropomorphic) descendant of the ancient sylvan folk believed to be responsible for the community's ordeals. Nor does the story allow for a sense of a happy resolution of the social and ecological crises, even though the missing children are safely returned 
to their families and the pending silver mining operations are temporarily suspended. In the ultimate episode, Eva has to let go of her dying daughter to assuage her unbearable suffering. With a tangible precision, Josefine is shown to pass over the boundary between human and other-than-human lifeform. Once her weakened body is carefully laid on the forest ground, her fingers and toes change into pliable roots penetrating the mossy vegetation and growing into the humid earth, her skin transforms into bark, and her torso morphs into a gnarled tree trunk. It is then that the full significance of the super powerful natural parasite to which the series owes its title becomes clear. Incorporated by the human body, jordskott enters into symbiodid with it. When treated with care, this alien organism ensures the body's continuing existence, as the story of Eva's recovery from the lethal gunshot testifies. The parasite also drastically enhances the physical, and especially the perceptual, capacities of the human being helping it to relate with other species in a conscious and organic way. But when neglected or maltreated, it irrevocably destroys the body's vital organs, causing agonising death, or even turns the person into a raging human monster wreaking havoc on its surroundings. As the forest's ambassador par excellence, jordskott ultimately re-affirms Olaf Gran's passionate declaration that nature urgently wants to tell us something.

\section{The power of televisual ecofiction}

As a part of the transnationally influential corpus of Nordic television drama with its rigorous attention to the world's most pressing cultural anxieties, Jordskott cannot be easily written off as a form of pure narrative entertainment. Together with other series discussed in this special issue, it consciously participates in raising public awareness of contemporary political, social, scientific, and technological challenges, or in what Robert Saunders (2017: 983) calls an "affective act of world-building", by offering long-lasting plot- and character-driven engagement. Dealing with the theme of ecological crisis Jordskott draws on famous predecessors such as Twin Peaks and Riget in its endeavour to lend visibility to the issue that, as film scholar J. P. Telotte (2014: para. 6) rightly points out, "can be terribly resistant to narrativization". Jordskott transcends rigid genre destinations and weaves mythologising and supernatural mysteries into realist narrative directories, prompting viewers to see the series as more than just a set of exciting stories. The inventive redistribution of human and nonhuman agency within the Gothic narrative frame allows us to unveil the link between natural ecology and cultural mythology. By presenting ecocide not solely as a biological phenomenon, but as a form of cultural crisis, Jordskott encourages its local and transnational audiences to ponder on the relationship of human morality and environmental change, and finally to start imagining ways of sustaining human evolution in a more-than-human world.

Finally, the later emulation of the genre-blending approach and the creative take on telefantasy by other successful series, for instance The Kettering Incident (Australia, 2016), Dark (Germany, 2017-), Black Spot (France, 2017-), and Ragnarok (Netflix, 2020-), affirms Jordkott's status as a foundational text in the growing category of green television drama and therein reinforces the geopolitically engaged position of Nordic small-screen productions. 


\section{Notes}

1. It is worth noting that the Nordic region is not unique in picking up ecocritical narrative as a topic for the serial drama. To name but a few successful examples, the intention to articulate critique towards humanity's destructive impact on the natural world resonates at the core of the Australian drama The Kettering Incident (2016), the British series Fortitude (2015-2018), and the French-Swedish coproduction Midnight Sun (2016).

2. It should be noted that such identification with the natural environment is not a uniquely Swedish phenomenon. Dianne Harris (2008: 193), for one, has argued that the sense of the personal and the national self can often be "produced through sets of mediated experiences in which both the particular and general characteristics of our surroundings play a part".

3. Interestingly, as Ruth McElroy (2013: para. 10) points out, this "aesthetic sensibility (wide angle shots cinematically showing bare and evocative landscapes ...) come to be increasingly seen as a measure of [the local places'] transnational appeal", which suggests that the Swedish forest in Jordskott operates both as a distinctly local setting and as an object of the transnational (tourist) gaze.

4. Morton emphasises that sitting back and contemplating environmental crises will not provide humankind with sustainable solutions. To that effect, he contends: "At some level, respecting other species and ecosystems involves a choice. This choice is saturated with contingency (it is our choice) and desire (we want something to be otherwise). There is no place outside the sphere of this contingent choice from which to stand and assess the situation - no 'nature' outside the problem of global warming that will come and fill us in on how to vote" (Morton, 2015: 255).

5. To theorise this, Morton invokes the notion of the Anthropocene, which was first introduced in 2000 by Paul Crutzen and Eugene Stoermer (2000) to denote the advent of a new geological epoch. The scholars argued that the impact of human activity has radically altered the Earth's ecosystems and climate and thus ended the Holocene during which major human civilizations developed over centuries.

\section{References}

Altman, R. (1999). Film/genre. London: British Film Institute.

Bettelheim, B. (2010). The uses of enchantment: the meaning and importance of fairy tales. New York: Vintage Books.

Brace, C., \& Johns-Putra, A. (2010). Introduction. In C. Brace, \& A. Johns-Putra (Eds.), Process: Landscape and text (pp. 19-25). New York: Rodopi.

Bruhn, J. (2018). Ecology as pre-text? The paradoxical presence of ecological thematics in contemporary Scandinavian quality TV. Journal of Aesthetics \& Culture, 10(2), 66-73. https://doi.org/10.1080/2000 4214.2018.1438729

Byatt, A. S. (2003, July 11). Harry Potter and the childish adult. New York Times. https://www.nytimes. com/2003/07/07/opinion/harry-potter-and-the-childish-adult.html

Creeber, G. (2004). Serial television: Big drama on the small screen. London: British Film Institute Publishing.

Creeber, G. (2015). Killing us softly: Investigating the aesthetics, philosophy and influence of Nordic Noir television. The Journal of Popular Television, 3(1), 21-35. https://doi.org/10.1386/jptv.3.1.21_1

Crutzen, P. J., \& Stoermer E. F. (2000). The Anthropocene. Global Change Newsletter, 41(May), 17-18.

Del Principe, D. (2014). Introduction: The ecoGothic in the long nineteenth century. Gothic Studies, 16(1), 1-8. https://doi.org/10.7227/GS.16.1.1

Donaghy, J. (2015a, June 9). Jordskott: The latest Swedish import brings a mythical edge to Scandi drama. The Guardian. https://www.theguardian.com/tv-and-radio/tvandradioblog/2015/jun/09/jordskott-thelatest-swedish-import-brings-a-mythical-edge-to-scandi-drama

Donaghy, J. (2015b, July 14). Murder, mystery, evil Swedish forests: Have you been watching Jordskott? The Guardian. https://www.theguardian.com/tv-and-radio/tvandradioblog/2015/jul/14/mystery-evil-swedishforests-have-you-been-watching-jordskott

Ghosh, A. (2016). The great derangement: Climate change and the unthinkable. Chicago: The University of Chicago Press.

Hall, S. (1980). Encoding/decoding. In S. Hall, D. Hobson, A. Lowe, \& P. Willis (Eds.), Culture, media, language: Working Papers in Cultural Studies, 1972-79 (pp. 128-138). London: Hutchinson. https:// doi.org/10.4324/9780203381182

Hansen, K. T., \& Waade, A. M. (2017). Locating Nordic Noir: From Beck to The Bridge. Basingstoke, UK: Palgrave. https://www.doi.org/10.1007/978-3-319-59815-4 
Harris, D. (2008). Self and landscape. In R. Z. DeLue, \& J. Elkins (Eds.), Landscape theory (pp. 187-194). New York: Routledge. https://doi.org/10.4324/9780203929834

Harrison, R. P. (1992). Forests: The shadow of civilization. Chicago: The University of Chicago Press.

Henning R., Jonasson, A., \& Degerman P. (2018). Introduction. In R. Henning, A. Jonasson, \& P. Degerman (Eds.), Nordic narratives of nature and environment: Ecocritical approaches to northern European literatures and cultures (pp. 1-18). New York: Lexington Books.

Hirons, P. (2015a, August 12). Interview. Henrik Björn, Jordskott. The Killing Times. https://thekillingtimestv. wordpress.com/2015/08/12/interview-henrik-bjorn-jordskott/

Hirons, P. (2015b, August 12). Review: Jordskott (S1 E10/10), Wednesday $12^{\text {th }}$ August, ITV Encore. The Killing Times. https://thekillingtimestv.wordpress.com/2015/08/12/review-jordskott-s1-e1010-wednesday12th-august-itv-encore

Ingram, D. (2013). The aesthetics and ethics of eco-film criticism. In S. Rust, S. Monani, \& S. Cubitt (Eds.), Ecocinema: Theory and practice (pp. 43-62). New York: Routledge.

Ivakhiv, A. (2008). Green film criticism and its futures. ISLE: Interdisciplinary Studies in Literature and Environment, 15(2), 1-28. https://www.jstor.org/stable/44086718

Jackson, R. (1981). Fantasy: The literature of subversion. London: Methuen.

Johnson, C. (2015). Telefantasy. In G. Creeber (Ed.), The television genre book, (pp. 56-59). London: Palgrave.

Kennedy, C., Kennedy, T., \& Kennedy M. (2010). Science fiction/fantasy films, fairy tales and control: Landscapes stereotypes on a wilderness to ultra-urban continuum. In G. Harper, \& J. Rayner (Eds.), Cinema and landscape: Film, nation and cultural geography (pp. 281-296). Chicago: Intellect.

Kääpä, P. (2014). Ecology and contemporary Nordic cinemas: From nation-building to ecocosmopolitanism. New York: Bloomsbury.

Lefebvre, M. (2007). Between landscape and setting in the cinema. In M. Lefebvre (Ed.), Landscape and film (pp. 19-60). London: Routledge.

Leffler, Y. (2013). The devious landscape in Scandinavian horror. In P. M. Mehtonen, \& M. Savolainen (Eds.), Gothic topographies: Language, nation building and "race” (pp. 141-153). Farnham: Ashgate. https:// doi.org/10.4324/9781315585437

Leyda, J. (2016). The cultural affordances of cli-fi. In J. Leyda, K. Loock, A. Starre, T. P. Barbosa, \& M. Rivera (Eds.), The dystopian impulse of contemporary cli-fi: Lessons and questions from a joint workshop of the IASS and JFKI (FU Berlin) (pp. 11-17). Potsdam: Institute for Advanced Sustainability Studies. https://doi.org/10.2312/iass.2016.026

Leyda, J. (2018). Petropolitics, cli-fi and Occupied. Journal of Scandinavian Cinema, 8(2), 83-101. https:// doi.org/10.1386/jsca.8.2.83_1

Maitland, S. (2012). From the forest. New England Review, 33(3), 7-17.

McElroy, R. (2013, November 15). What can Wales learn from Nordic Noir? CST Online. https://cstonline. net/what-can-wales-learn-from-nordic-noir-by-ruth-mcelroy

Meinig, D. W. (1979). Symbolic landscapes: Some idealizations of American communities. In D. W. Meinig (Ed.), The interpretation of ordinary landscapes: Geographical essays (pp. 164-192). Oxford: Oxford University Press.

Messerli, A. (2005). Spatial representation in European popular fairy tales. Marvels \& Tales: Journal of Fairy-Tale Studies, 19(2), 274-284.

Morton, T. (2010). The ecological thought. Cambridge, Massachusetts: Harvard University Press.

Morton, T. (2013). Hyperobjects: Philosophy and ecology after the end of the world. Minneapolis: University of Minnesota Press.

Morton, T. (2015). Imagining ecology without nature. In K. Hiltner (Ed.), Ecocriticism: The essential reader (pp. 237-258). New York: Routledge.

Morton. T. (2016). Dark ecology: For a logic of future co-existence. New York: Columbia University Press.

Mrozewicz, A. E. (2018). Beyond Eastern noir: Reimaging Russia and Eastern Europe in Nordic cinemas. Edinburgh: Edinburgh University Press.

Neale, S. (2000). Genre and Hollywood. London: Routledge.

Nelson, R. (2015). Life on Mars: Genre hybridity with a twist. In G. Creeber (Ed.), The television genre book (pp. 10-11). London: Palgrave.

Nordic Council of Ministers. (2017). New Nordic cooperation programme for the environment and climate. https://www.norden.org

Nordic Fantasy. (2017, October 18). Jordskott 2 Preview. https://nordicfantasy.wordpress.com/2017/10/18/ jordskott-2-preview

Peacock, S. (2009). Two kingdoms, two kings. Critical Studies in Television: The International Journal of Television Studies, 4(2), 24-36.

Rees, E. R. (2016). Privilege, innocence and "petro-guilt" in Maria Sodahl's Limbo. Scandinavian Studies, 88(1), 42-59. https://www.doi.org/10.5406/scanstud.88.1.42 
Irina Souch

Roberts, L. (2016). Landscapes in the frame: Exploring the hinterlands of the British procedural drama. New Review of Film and Television Studies, 14(3), 364-385. https://doi.org/10.1080/17400309.2016.1189712

Rust, S., \& Monani, S. (2013). Introduction. In S. Rust, S. Monani, \& S. Cubitt (Eds.), Ecocinema: Theory and practice (pp. 1-13). New York: Routledge.

Saunders, R. A. (2017). Geopolitical television at the (b)order: Liminality, global politics, and world-building in The Bridge. Social \& Cultural Geography, 20(7), 981-1003. https://doi.org/10.1080/14649365.20 17.1404122

Smith, A., \& Hughes, W. (2013). Introduction: Defining the ecogothic. In A. Smith, \& W. Hughes (Eds.), Ecogothic (pp. 1-14). Manchester: Manchester University Press.

Smyth, A. (2015, June 9). Moa Gammel and producer Filip Hammarström discuss 'Jordskott'. Nordic Noir Newsletter. http://nordicnoir.tv/news/moa-gammel-and-producer-filip-hammarstrom-discuss-jordskott/

Spiegel, L. (2001). Welcome to the dreamhouse: Popular media and postwar suburbs. London: Duke University Press.

Tangherlini, T. R. (2001). Ghost in the machine: Supernatural threat and the state in Lars von Trier's "Riget." Scandinavian Studies, 73(1), 1-24. https://www.jstor.org/stable/40920275

Telotte, J. P. (2014, July 30). Science fiction reflects our anxieties. The New York Times. https://www.nytimes. com/roomfordebate/2014/07/29/will-fiction-influence-how-we-react-to-climate-change/science-fictionreflects-our-anxieties

Thomas, S. R. (2014, July 29). Imagination will help find solutions to climate change. The New York Times. https://www.nytimes.com/roomfordebate/2014/07/29/will-fiction-influence-how-we-react-to-climatechange/imagination-will-help-find-solutions-to-climate-change

Trimble, S. (2019). Scandinavian folklore. http://www.ststlocations.com/Archives/Scandinavian/Folklore/

Tyburski, S. J. (2015). Seduced by the wild: Audrey Shulman's ecoGothic romance. In E. Redling, \& C. Schneider (Eds.), Gothic transgressions: Extension and commercialization of a cultural mode (pp. 133-145). Zurich: LIT.

Waade, A. M. (2017). Melancholy in Nordic Noir: Characters, landscapes, light and music. In Critical Studies of Television, 12(4), 380-394. https://doi.org/10.1177/1749602017729629

World Wild Fund For Nature (WWF). (2014). Living planet report 2014. https://www.worldwildlife.org/ pages/living-planet-report-2014

Wright, R. (2010). Vampire in the Stockholm suburbs: Let the Right One In and genre hybridity. Journal of Scandinavian Cinema, 1(1), 55-70. https://doi.org/10.1386/jsca.1.1.55_1

Zaremba, M. (2013). Skogen vi ärvde [The forest we inherited]. Dagens Nyheter: EPUB.

Zipes, J. (2002) The brothers Grimm: From enchanted forests to the modern world. New York: Palgrave Macmillan. https://www.doi.org/10.1007/978-1-137-09873-3

Žižek, S. (1992). Looking awry: An introduction to Lacan thought through popular culture. Cambridge, Massachusetts: MIT Press.

Copyright: (C) 2020 The Author(s) and Nordicom. This is an Open Access article distributed under the terms of the Creative Commons Attribution 4.0 International License (CC BY-NC-ND 4.0). 